\title{
Induction of Salicylic Acid-Mediated Defense Response in Perennial Ryegrass Against Infection by Magnaporthe oryzae
}

\author{
Alamgir Rahman, Gretchen A. Kuldau, and Wakar Uddin
}

Department of Plant Pathology \& Environmental Microbiology, The Pennsylvania State University, University Park 16802. Accepted for publication 25 November 2013.

\begin{abstract}
Rahman, A., Kuldau, G. A., and Uddin, W. 2014. Induction of salicylic acid-mediated defense response in perennial ryegrass against infection by Magnaporthe oryzae. Phytopathology 104:614-623.

Incorporation of plant defense activators is an innovative approach to development of an integrated strategy for the management of turfgrass diseases. The effects of salicylic acid (SA), benzothiadiazole (BTH, chemical analog of SA), jasmonic acid (JA), and ethephon (ET, an ethylene-releasing compound) on development of gray leaf spot in perennial ryegrass (Lolium perenne L.) caused by Magnaporthe oryzae were evaluated. Gray leaf spot disease incidence and severity were significantly decreased when plants were treated prior to inoculation with SA,

BTH, and partially by ET but not by JA. Accumulation of endogenous SA and elevated expression of pathogenesis-related $(P R)-1, P R-3.1$, and $P R-5$ genes were associated with inoculation of plants by $M$. oryzae. Treatment of plants with SA enhanced expression levels of $P R-3.1$ and $P R-5$ but did not affect the $P R-1$ level, whereas BTH treatment enhanced relative expression levels of all three $P R$ genes. Microscopic observations of leaves inoculated with $M$. oryzae revealed higher frequencies of callose deposition at the penetration sites in SA- and BTH-treated plants compared with the control plants (treated with water). These results suggest that early and higher induction of these genes by systemic resistance inducers may provide perennial ryegrass with a substantial advantage to defend against infection by $M$. oryzae.
\end{abstract}

Perennial ryegrass (Lolium perenne L.) is one of the most important turf, pasture, and forage grasses in the world (41). It possesses all the desirable agronomic characteristics, such as rapid germination, upright growth, dark green color, and tolerance to close mowing, making it a major cool-season turfgrass species (55). As a result of its widespread use in the turf industry, a number of fungal pathogens that can cause severe diseases in perennial ryegrass have emerged during the past two decades. Among them, gray leaf spot disease, caused by Magnaporthe oryzae B. C. Couch, has become one of the most devastating diseases of perennial ryegrass (13). The pathogen is also known to cause severe blast diseases on important cereal crops such as rice (Oryzae sativa L.) and wheat (Triticum aestivum L.), as well as several other turfgrass species such as St. Augustinegrass (Stenotaphrum secundatum (Walt.) Kuntze), tall fescue (Festuca arundinacea Schreb.), and kikuyugrass (Pennisetum clandestinum Hochst.) $(55,61)$. Although newly planted perennial ryegrass turf have been found to be more susceptible to $M$. oryzae infection than established turf, under favorable environmental conditions, the pathogen can cause extensive damage to mature perennial ryegrass in golf course fairways and athletic fields $(35,55)$. Available management methods to control the disease include cultural management practices such as reduction of turf canopy moisture, lowering cutting height, and fungicide application $(35,59)$. However, cultural management practices are often ineffective because of the rapid progression of the disease epidemic (35). Additionally, widespread use of fungicides has led to fungicide-resistance (59), could result in new strains resistant to the existing effective fungicides, and could negatively affect the soil

Corresponding author: W. Uddin; E-mail address: wxu2@psu.edu

* The $e$-Xtra logo stands for "electronic extra" and indicates that Figure 4 appears in color online.

http://dx.doi.org/10.1094/PHYTO-09-13-0268-R

(c) 2014 The American Phytopathological Society beneficial microorganisms (32). All these may add significant cost to turf management.

In recent years, exploitation of host defense responses to control plant diseases has been considered to be one of the most promising strategies in integrated management of diseases (39). Management of blast disease by employing host resistance has been well documented in several economically important cereal crops $(44,50)$. Major race-specific resistance $(R)$ genes providing complete resistance as well as quantitative trait loci (QTLs) providing partial but durable disease resistance have been reported in both of these crops to protect from disease caused by M. oryzae (44). Regardless of the type of resistance, gene-specific or partial, the regulation of such defense response is critically dependent on the accumulation of specific phytohormones that are carefully controlled by the host plant upon pathogen infection (38). For instance, during $R$-gene-mediated resistance against biotrophic pathogens, rapid production of reactive oxygen species (ROS) at the site of pathogen invasion results in the hypersensitive response (HR) (38). At the same time, systemic resistance is activated to distal parts of the plant through the salicylic acid (SA)-mediated signaling pathway, known as systemic acquired resistance (SAR), resulting in the induction of several pathogenesis-related $(P R)$ genes which are thought to contribute to disease resistance (9). SA has also been found to play similar role as a signal transducer of SAR during basal or innate immunity (54) but usually without the corresponding HR (28). As a consequence, considerable overlaps exist between the two types of resistance, including cell wall fortification through the synthesis of callose and papilla and the accumulation of a wide range of antimicrobial compounds such as phytoalexins and PR proteins (25). PR proteins occur widely in the plant kingdom and comprise a large group of 17 protein families (57). These include PR-1 (unknown function), $\beta$-1,3-glucanase (PR-2), endochitinases (PR-3, PR-4, PR-8, and PR-11), thaumatin-like (PR-5), proteinase inhibitors (PR-6), proteinase (PR-7), peroxidase (PR-9), ribonuclease-like (PR-10), defensins (PR-12), thionins (PR-13), lipidtransfer proteins (PR-14), and, more recently included, oxalate 
oxidase (PR-15), oxalate oxidase-like (PR-16), and PR-17 (unknown). These PR proteins have been reported to play important roles in plant defense against biotic and abiotic stresses (55). Protective roles of several PR proteins have also been documented through their accumulation in papillae (cell wall appositions). Papilla formation is characterized by localized deposition of callose and other constituents, including $\mathrm{H}_{2} \mathrm{O}_{2}$ and PR proteins, by the epidermal cells bellow the attempted site of fungal penetration to prevent pathogen ingress (64).

Apart from pathogen infection, SAR can also be induced by the application of a number of synthetic SA chemical analogs such as benzo $(1,2,3)$ thiadiazole-7-carbothioic acid- $S$-methyl ester (BTH), 2,6-dichloroisonicotinic acid (DCINA), and 3-allyloxy-1,2benziso-thiazole-1,1-dioxide (probenazole) as well as exogenous application of plant hormones such as SA, jasmonic acid (JA), or ethylene $(1,38)$. However, considerable differences exist between monocots and dicots in SAR activation (1). Accumulation of SA followed by activation of the $P R-1$ gene has been demonstrated to be an indispensable element for SAR in several dicots (37) but their role in monocotyledonous plants is not as clear (1). For instance, barley infection with Blumeria graminis f. sp. hordei resulted in elevated expression of $P R-1 a \& b, P R-2, P R-3$, and $P R-5$ genes without concomitant accumulation of endogenous SA (56). However, exogenous application of DCINA and BTH resulted in strong systemic resistance in barley against the same biotrophic pathogen but only very weakly by SA (2). In rice, exogenous application of JA resulted in stronger activation of defense response genes PRla, PRIb, PR2, PR3, PR5, and PR10 compared with SA, which provided protection against blast disease (27). In wheat-powdery mildew interaction, infection with Erysiphe graminis f. sp. tritici resulted in enhanced expression of $P R-1.1$ and $P R-1.2$ genes but not by any of the SAR activators; namely, SA, BTH, and INA (isonicotinic acid) (30). However, application of SA has been reported to enhance expression of $P R$ $2,-3$, and -5 in wheat (24). Moreover, other basal defense responses such as callose deposition and papillae formation have been found to be enhanced by SA and BTH in both dicots (12) and monocots (48) in response to pathogen infection. Information on similar defense mechanisms in perennial ryegrass following exogenous application of plant hormones or their synthetic chemical analogs and pathogen challenge would be very useful for developing an effective management strategy in combination with host resistance and conventional fungicides.

When compared with $R$-gene-mediated resistance, partial or basal resistance has been found to be more durable and longlasting in cereal crops against biotrophic fungal pathogens based on field experiments (5). Co-localization of defense-related QTLs and $P R$ genes have been reported in both monocots (5) and dicots (8). Furthermore, enhanced expression of $P R$ genes has been frequently documented to be associated with resistant cultivars of both eudicotyledonous (20) and monocotyledonous (34) plants. In perennial ryegrass, no major $R$ gene against $M$. oryzae has yet been documented. However, several QTLs for resistance against gray leaf spot disease in perennial ryegrass have been identified that are associated with resistance of a partial rather than complete nature (5). A number of these QTLs were later found to confer partial resistance against other fungal diseases such as stem rust, crown rust, and leaf spot (17). Later, co-localization of several of these QTLs with that of defense-related genes in perennial ryegrass-namely, LpPERa (peroxidase class III), LPDEFa (defensin), LpCAT (catalase), and LPOXO (oxalate oxidase) - were reported (6). However, expression analysis of any $P R$ genes in relation to $M$. oryzae infection in perennial ryegrass has not yet been determined. Timing and magnitude of $P R$ gene expression following pretreatments with SAR activators in perennial ryegrass would be valuable for developing an integrated management strategy of gray leaf spot disease, thereby reducing the total reliance on conventional chemical fungicides.
Accumulation of plant defense-related hormone or expression levels of any $P R$ genes in response to SAR activators and $M$. oryzae infection in perennial ryegrass is unknown. Therefore, the primary objective of this study was to elucidate the role of SA-mediated defense responses in perennial ryegrass against M. oryzae infection.

\section{MATERIALS AND METHODS}

Plant materials and chemical treatments. All experiments were conducted in controlled-environment chambers (CONVIRON, model PGR 15; Canada). 'Legacy-II' perennial ryegrass (L. perenne L.), a cultivar highly susceptible to infection by $M$. oryzae, was seeded at a rate of $20 \mathrm{~g} / \mathrm{m}^{2}$ in plastic pots $(10.2 \mathrm{~cm}$ in diameter $)$ in Farfard mix number 2 (Griffin Greenhouse and Nursery Supplies, Leola, PA) and sand by volume (2:1). Farfard number 2 contains $55 \%$ peat moss, $20 \%$ perlite, and $25 \%$ vermiculite. Four-week-old plants grown at $24^{\circ} \mathrm{C}$ with 14 -h day $/ 10$-h night cycle were treated with different concentrations of SA (Sigma-Aldrich, St. Louis), BTH (Actigard, 50WG; Syngenta Crop Protection, Greensboro, NC), and 2-chloroethylphosphonic acid (ethephon [ET], which decomposes to ethylene when taken up by plants) (Sigma-Aldrich) as root drench and JA (Sigma-Aldrich) as a foliar spray. Treatment solutions were prepared by dissolving SA, Actigard 50WG (a 50\% active ingredient of BTH), and ET in deionized water to make stock concentrations of 20,50 , and $100 \mathrm{mM}$, respectively. They were then diluted to the desired final concentrations. JA was first dissolved in $100 \%$ ethanol to a stock concentration of $100 \mathrm{mM}$ and then diluted in deionized water to make the final concentrations as per requirement. All treatments were applied 2 days prior to pathogen inoculation unless otherwise stated.

Inoculation of the plants with $M$. oryzae and disease rating. An isolate of $M$. oryzae (PgPA 05T-01) that was maintained on filter paper strips at $-80^{\circ} \mathrm{C}$, was used for all inoculations in this study (53). Preparation of $M$. oryzae conidia was the same as describe by Nanayakkara et al. (35). In brief, potato dextrose agar blocks ( $\approx 2$ by $2 \mathrm{~mm}$ ) containing actively growing fungal mycelia of $M$. oryzae were transferred to oatmeal agar. After 5 days of incubation at 25 to $26^{\circ} \mathrm{C}$ under fluorescent light $\left(72 \mu \mathrm{E} \mathrm{m} \mathrm{m}^{2}\right)$, $\approx 3$-cm-long alfalfa (Medicago sativa L.) stems, sterilized by autoclaving twice, were placed in the culture plates and incubated under the same conditions to induce sporulation on the stems. After 12 to 14 days of incubation, conidia were harvested and adjusted to 3 to $4 \times 10^{4}$ conidia/ml with sterile MilliQ water $(0.01 \%$ Tween 20). Four-week-old perennial ryegrass plants were inoculated with the conidial suspension by atomizing the leaves until run-off. Plants atomized with sterile MilliQ water containing $0.01 \%$ Tween 20 (Sigma-Aldrich) served as noninoculated control plants. Immediately after inoculation, plants were placed under continuous fluorescent light ( 77 to $85 \mu \mathrm{E} \mathrm{m} \mathrm{m}^{2} \mathrm{~s}^{-1}$ ) at $28^{\circ} \mathrm{C}$ and relative humidity of $>95 \%$ in a Percival dew chamber (model E 54U-DL; Boone, IA). Plants were arranged in a randomized complete block design with three replications for each treatment. Disease incidence and severity were assessed 5 days after inoculation with Magnaporthe oryzae, as described by Nanayakkara et al. (35). Disease incidence was assessed by quantifying percent symptomatic leaves in each treatment. Disease severity was assessed using an index of 0 to $10(0=$ no necrosis and $10 \geq 90 \%$ necrotic leaf area on individual blades). The experiments were repeated once. Data from each experiment were subjected to analysis of variance (ANOVA) using MINITAB (version 16.1.0; Minitab Inc., State College, PA). Multiple comparisons of means for disease incidence and severity were made using StudentNewman-Keul's test $(P \leq 0.05)$.

Determination of endogenous levels of SA. Leaf samples at five time points $(0,12,24,48$, and $72 \mathrm{~h}$ relative to pathogen inoculation) were collected, weighed, frozen in liquid nitrogen, and stored at $-80^{\circ} \mathrm{C}$. SA and SA conjugates were extracted and 
analyzed as described by Raskin et al. (42) and modified by Bowling et al. (4). A tissue sample (1 g) was homogenized in $3 \mathrm{ml}$ of $90 \%$ methanol with a mortar and pestle. The extract was then centrifuged at $12,000 \times g$ for $15 \mathrm{~min}$. The pellet was resuspended in $100 \%$ methanol, reextracted by vortexing for $1 \mathrm{~min}$, and centrifuged at $12,000 \times g$ for another $15 \mathrm{~min}$. Supernatants from both extractions were combined and dried under nitrogen stream at $40^{\circ} \mathrm{C}$. The residues were resuspended in $2.5 \mathrm{ml}$ of $5 \%(\mathrm{wt} / \mathrm{vol})$ tricholoroacetic acid and sonicated for $10 \mathrm{~min}$. Free SA was then separated from conjugated SA through organic extraction with two volumes of ethylacetate/cyclopentane/isopropanol (50:50:1). The organic phase containing free SA was then dried under a nitrogen stream. The dried extract was resuspended in $250 \mu \mathrm{l}$ of $20 \%$ methanol, filtered through a $0.45-\mu \mathrm{m}$ polyvinylidene diflouride membrane (PALL Life Sciences, New York), and stored at $-80^{\circ} \mathrm{C}$ until high-performance liquid chromatography (HPLC) analysis. For quantification of SA conjugates (SA-2-O- $\beta$-Dglucoside $[\mathrm{SAG}])$, the aqueous phase, following phase separation, was acidified with $\mathrm{HCl}$ to $\mathrm{pH} 1$ and boiled for 30 min to release SA from any acid labile-conjugated forms. The released free SA was then extracted with the organic mixture and stored as previously described. SA was identified and quantified by reversedphase (RP)-HPLC (1100 series; Agilent Technologies) fitted with a 5 - $\mu \mathrm{m}$ C-18 column (150 by $4.6 \mathrm{~mm}$ ) (Ultra II Aqueous Restek, Bellefonte, PA) at a flow rate of $0.6 \mathrm{ml} / \mathrm{min}$. For HPLC analysis, a $50-\mu \mathrm{l}$ sample was injected and a step-gradient elution was performed using $20 \mathrm{mM}$ sodium acetate (in $20 \%$ methanol), $\mathrm{pH}$ 5.0, as solvent $\mathrm{A}$ and $20 \mathrm{mM}$ sodium acetate (in $70 \%$ methanol), $\mathrm{pH} 5.0$, as solvent B. Separation conditions were a 15-min gradient from 5 to $30 \%$ solvent $\mathrm{B}$, followed by $100 \%$ and reequilibration at $5 \%$ solvent B. Fluorescent detection was performed with a band-pass filter (excitation energy of $295 \mathrm{~nm}$ and emission energy of $400 \mathrm{~nm}$ ). A six-point standard curve of standard SA (Sigma-Aldrich) at concentrations of 0 to $1,000 \mathrm{ng} / \mathrm{ml}$ was used for SA quantification. The procedure had a recovery rate of 60 to $65 \%$ for extractable SA, as determined by spiking tissue samples with standard SA. The lowest concentration of SA reliably quantifiable by the procedure was $10 \mathrm{ng} / \mathrm{g}$ fresh weight (FW). All experiments were repeated twice and data from each time point were subjected of ANOVA followed by pairwise comparison using Fisher's protected least significant difference test using MINITAB (version 16.1.0: Minitab Inc.).

Tissue collection and RNA extraction. Leaf samples were collected and stored as described earlier in the endogenous SA extraction method following pathogen inoculation or chemical treatments. Total RNA was isolated using TRIzol reagent (Life Technologies, Grand Island, NY) as described in the manufacturer's protocol. In brief, $0.1 \mathrm{~g}$ of leaf tissue was ground to fine powder in liquid nitrogen and then mixed with $1 \mathrm{ml}$ of TRIzol reagent. The mixture was incubated at room temperature for $5 \mathrm{~min}$. The samples were mixed thoroughly with $200 \mu \mathrm{l}$ of chloroform (Acros Organics; Thermo Fisher Scientific, NJ), then centrifuged for $15 \mathrm{~min}$ at $13,000 \times g$ at $4^{\circ} \mathrm{C}$. The upper aqueous layer was transferred to a new RNase-free tube and $500 \mu \mathrm{l}$ of isopropyl alcohol (Mallinckrodt Baker, Inc., Phillipsburg, NJ) was added, vortexed thoroughly, and incubated for $10 \mathrm{~min}$ at room temperature. Following centrifugation for $10 \mathrm{~min}$ at $13,000 \times \mathrm{g}$ at $4^{\circ} \mathrm{C}$, the RNA pellet was washed twice with $75 \%$ ethanol and resuspended in diethylpyrocarbonate (Amresco, Inc.)-treated water. The quality of RNA was examined by electrophoresis in $1.2 \%$ agarose formaldehyde gel.

Analysis of gene expression using quantitative real-time polymerase chain reaction. Two-step real-time polymerase chain reaction (PCR) was performed using the Applied Biosystems 7300 Real-Time PCR System (Life Technologies). Concentration of total RNA was determined by Nanodrop spectrophotometer (NanoDrop 2000c; Thermo Scientific, Wilmington, DE). Total RNA $(2 \mu \mathrm{g})$ was treated with DNase I (NEB, Ipswich, MA) at room temperature for $30 \mathrm{~min}$ and the reaction was stopped by adding $1 \mu \mathrm{l}$ of $25 \mathrm{mM}$ EDTA and heating at $75^{\circ} \mathrm{C}$ for $10 \mathrm{~min}$. Generation of cDNA was performed with High-Capacity cDNA Reverse Transcription Kit (Applied Biosystems, Life Technologies) using oligo (dT) primers according to the manufacturer's instructions. The resultant cDNA was then diluted 10 times and kept at $-80^{\circ} \mathrm{C}$ for quantitative PCR. To quantify altered gene expression as a result of chemical treatments followed by $M$. oryzae infection, specific primers for four perennial ryegrass genes-PR-1, PR-3.1, PR-5, and (stably expressed eukaryotic elongation factor $1 \alpha[e E F 1 A(s)]$ )—were used for each cDNA sample (Table 1). Primers for $P R-3.1$ were designed based on the partial nucleotide sequence of $L$. perenne $P R-3.1$ (accession number HQ229924.1). Each primer pair was chosen based on the amplification efficiency between a target and the reference gene $(e E F 1 A(s))$, which was determined as described by Livak and Schmittgen (23). The specification of each pair of primers was also confirmed by randomly sequencing PCR products and further consolidated by the melting curve analysis using real-time PCR. The real-time quantitative PCR was conducted using the SYBR Green PCR Master Mix (Applied Biosystems, Life Technologies) as recommended by the manufacturer. PCR reactions were carried out in triplicate in 96-well plates ( $25 \mu \mathrm{l}$ per well) in a buffer containing $1 \times$ SYBR Green (including Taq polymerase, dNTPs, and SYBR Green dye) and $100 \mathrm{nM}$ each primer (forward and reverse). After denaturation at $95^{\circ} \mathrm{C}$ for $15 \mathrm{~min}$, a two-step amplification occurred: $15 \mathrm{~s}$ of denaturation at $95^{\circ} \mathrm{C}, 30 \mathrm{~s}$ of annealing at $60^{\circ} \mathrm{C}$, and a 30 -s extension at $72^{\circ} \mathrm{C}$, for a total of 45 cycles. Identical thermal cycling was used for all targets. The transcript levels were normalized against the perennial ryegrass $e E F 1 A(s)$ gene. Results from several previous works indicated $e E F 1 A(s)$ as one of the best usable housekeeping genes to normalize gene expression levels because it was found to be stably expressed during stress, during various phases of development, and in different environmental conditions (22). For each gene, the sample value at the $0 \mathrm{~h}$ time of the untreated healthy control was defined as the calibrator sample and results were expressed as the fold change of mRNA over this sample using the comparative threshold method $\left(2^{-\Delta \Delta \mathrm{Ct}}\right)$ (23). Average threshold cycle $(\mathrm{Ct})$ normalized to $e E F I A(s)$ transcript for each condition as $2^{-\Delta \mathrm{Ct}}$ and fold changes were calculated as $2^{-\Delta \Delta \mathrm{Ct}}(23)$. Negative controls lacking cDNA were routinely included. Melting curve analysis of the amplification products was performed at the end of each PCR reaction to ensure that a single PCR was detected. All experi-

TABLE 1. DNA primers used to assay the gene expression by quantitative real-time polymerase chain reaction

\begin{tabular}{|c|c|c|c|c|}
\hline Gene & Primer & Primer sequence $\left(5^{\prime}-3^{\prime}\right)$ & Product size (bp) & Reference \\
\hline \multirow[t]{2}{*}{$P R-1$} & Forward & ACGGCGAGAACATCTTCTGG & 207 & 50 \\
\hline & Reverse & CGCCGAGGTTGTTGTCGCAG & $\ldots$ & $\ldots$ \\
\hline \multirow[t]{2}{*}{$P R-3.1$} & Forward & АСТСТTCССТTGTACССТАСC & 144 & This study \\
\hline & Reverse & TTTTGAAGGAGATCACCGGG & $\ldots$ & $\ldots$ \\
\hline \multirow[t]{2}{*}{$P R-5$} & Forward & GCCAGTGGGCGGTGGTAGGC & 261 & 50 \\
\hline & Reverse & ATGCCGATGTTGAACCCGTC & $\ldots$ & $\ldots$ \\
\hline \multirow[t]{2}{*}{$e E F 1 A(s)$} & Forward & CCGTTTTGTCGAGTTTGGT & 113 & 22 \\
\hline & Reverse & AGCAACTGTAACCGAACATAGC & $\ldots$ & $\ldots$ \\
\hline
\end{tabular}


ments were performed three times and each real-time PCR sample was run in triplicate. Data from each experiment were subjected to ANOVA using MINITAB (version 16.1.0; Minitab Inc.). Differences among treatments were evaluated using StudentNewman-Keul's test at each time point and $P$ values $<0.05$ were considered statistically significant (29).

Aniline blue staining and analysis of callose deposition. To evaluate perennial ryegrass response to treatments and infection by $M$. oryzae, aniline blue staining was performed to detect the deposition of callose at the infection sites based on a protocol developed by Hood and Shew (14) and modified by Orshinsky et al. (36). Briefly, leaf segments (3 cm in length) were collected from the middle part of the inoculated leaves and were transferred to an of ethanol/acetic acid solution $(3: 1, \mathrm{vol} / \mathrm{vol})$ for at least $24 \mathrm{~h}$ until all tissues were completely cleared of chlorophyll. Following three washes in $0.067 \mathrm{M} \mathrm{K}_{2} \mathrm{HPO}_{4}$ buffer ( $\mathrm{pH}$ 9), leaf segments were incubated for $2 \mathrm{~h}$ in $0.067 \mathrm{M} \mathrm{K}_{2} \mathrm{HPO}_{4}$ buffer containing $0.05 \%$ aniline blue (Acros Organics; Thermo Fisher Scientific). The samples were then mounted in $50 \%$ (vol $/ \mathrm{vol})$ glycerol for microscopic analysis. Callose-stained segments were visualized using eplifluorescence microscopy with a UV filter (Olympus BX-61; excitation filter 350/50 nm; DM 400 dichroic beam splitter and emission filter $460 / 50 \mathrm{~nm}$ ). Images were acquired digitally (Hamamatsu cooled digital camera: ORCA ER [Model C4742-80] and Olympus DP71) and further processed with the CellSens Dimension software. ANOVA of the percentage of infection sites with callose deposition was calculated using MINITAB (version 16.1.0; Minitab Inc.) followed by Tukey's multiple comparison tests among interactions.

\section{RESULTS}

Effect of SA on disease incidence. To verify the effectiveness of different concentrations of SA (1.5, 2.5, and $3.5 \mathrm{mM})$, $M$. oryzae conidia were inoculated on perennial ryegrass after 0 , 1,2 , and 3 days of treatment application. There were significant difference in gray leaf spot disease incidence between the untreated control and SA treatments $(1.5,2.5$, and $3.5 \mathrm{mM})$ applied on day $0(P<0.0001$ for all treatments $)$, day $1(P=0.013$, 0.0172 , and 0.0083 , respectively), and day $2(P=0.0086,0.0134$, and 0.0054 , respectively) but not on day $3(P=0.4928,0.9529$, and 0.3647 , respectively) (Fig. 1A). However, disease incidence values for the $1.5-\mathrm{mM} \mathrm{SA}$ treatment did not vary significantly from the other two concentrations of SA treatments (2.5 and $3.5 \mathrm{mM})$ applied on day $0(P=0.122$ and 0.0581 , respectively $)$, day $1(P=0.8496$ and 0.7243 , respectively $)$, day $2(P=0.2901$ and 0.3556 , respectively), and day $3(P=0.2964$, and 0.5846 , respectively).

Effect of BTH, JA, and ET on disease incidence. The effect of different concentrations of BTH, JA, and ET varied greatly in suppressing the gray leaf spot disease incidence in perennial ryegrass. All three different concentrations of BTH (1.0, 2.5, and $5 \mathrm{mM})$ exhibited significant $(P=0.0018,0.0018$, and 0.0011 , respectively) suppression of disease incidence when compared with the untreated control, with control up to 35.77, 42.33, and $49.65 \%$, respectively (Table 2). However, disease incidence values for $1.0 \mathrm{mM} \mathrm{BTH}$, the lowest concentration applied, did not vary significantly $(P=0.3681$ and 0.1791 , respectively) compared with the other two BTH treatments (namely, 2.5 and $5 \mathrm{mM}$ ). On the other hand, disease incidence values between the untreated control and the JA treatments $(0.1,0.5$, and $1 \mathrm{mM})$ did not show any significant $(P \leq 0.05)$ difference (Table 2$)$. Effect of ET treatments varied based on concentrations; $0.5 \mathrm{mM}$ had a significantly $(P=0.0388)$ different disease incidence value, whereas no significant differences $(P \leq 0.05)$ were observed with 2.5 and $5 \mathrm{mM}$ concentrations of ET treatments compared with the untreated control plants. There were also no significant differences $(P \leq 0.05)$ among the ET treatments.
Effect of SA on disease severity. Disease severity values of SA-treated $(1.5,2.5$, and $3.5 \mathrm{mM})$ plants varied significantly applied on day $0(P<0.0001)$ and day $2(P=0.0199,0.0237$, and 0.0214 , respectively) but did not vary significantly on day $3(P=$ $0.2956,0.9597$, and 0.3985 , respectively) when compared with untreated control plants (Fig. 1B). On day 1, the untreated control varied significantly $(P=0.0406)$ only compared with the $1.5-\mathrm{mM}$ SA treatment but not with the other two SA treatments (namely, 2.5 and $3.5 \mathrm{mM})(P=0.0818$ and 0.135 , respectively). However, there were no significant differences $(P \leq 0.05)$ in gray leaf spot disease severity values among the three SA treatments regardless of the treatment application time.

Effect of BTH, JA, and ET on disease severity. All three concentrations of BTH applied $(1.0,2.5$, and $5 \mathrm{mM})$ exhibited significant differences $(P=0.0014,0.0018$, and 0.0014 , respectively) compared with the untreated control in disease severity values. However, $1.0 \mathrm{mM}$ BTH treatment did not vary significantly $(P \leq 0.05)$ compared with 2.5 and $5 \mathrm{mM} \mathrm{BTH}$ concen-
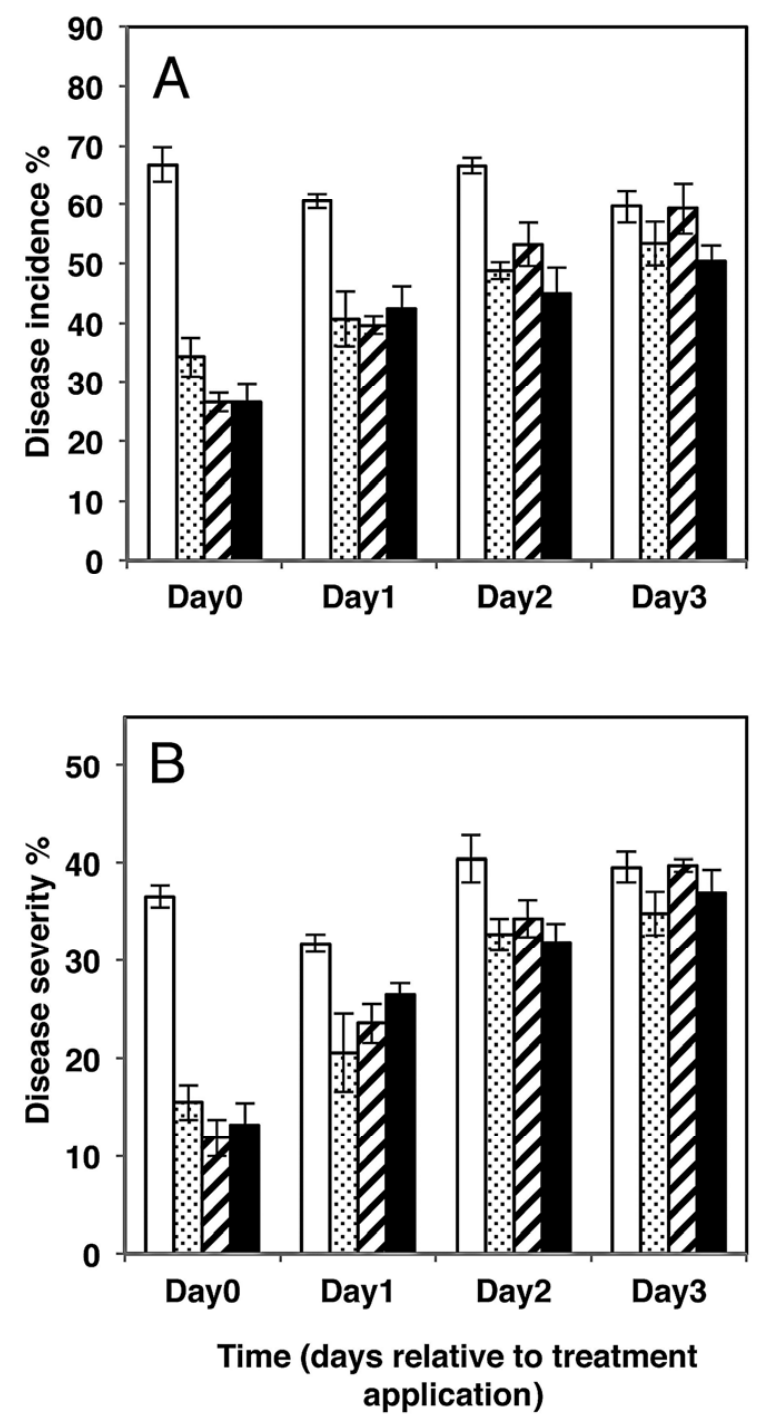

口Control $\quad \square 1.5 \mathrm{mM} \quad \square 2.5 \mathrm{mM} \quad \square 3.5 \mathrm{mM}$

Fig. 1. Effects of application timing of different concentrations of salicylic acid (SA) (days prior to inoculation of plants with Magnaporthe oryzae) on A, incidence and $\mathbf{B}$, severity of gray leaf spot disease in perennial ryegrass turf. Solid white bars $=$ untreated control plants, dotted bars $=1.5 \mathrm{mM}$ SA-treated plants, stripped bars $=2.5 \mathrm{mM}$ SA-treated plants, and black bars $=3.5 \mathrm{mM}$ SA-treated plants. Each bar represents average percentage of disease incidence for three replicates ( \pm standard error). 
trations in their disease severity values (Table 2). On the other hand, none of the JA treatments $(0.1,0.5$, and $1 \mathrm{mM})$ showed any significant difference in disease severity values compared with the untreated control $(P \leq 0.05)$. Among the different concentrations of ET applied, only the lowest concentration (that is, $0.5 \mathrm{mM})$ had a significantly $(P=0.0389)$ different disease severity value, whereas 2.5 and $5 \mathrm{mM}$ ET treatments did not show any significant difference $(P \leq 0.05)$ compared with the untreated control plants. However, there were no significant differences $(P \leq 0.05)$ in disease severity values among the ET treatments (Table 2).

Elevation of endogenous SA in perennial ryegrass. Changes in the levels of free SA and SA conjugates (SAG) at different time points were determined after inoculation with $M$. oryzae conidia (Fig. 2). Endogenous concentration of free SA was found to be $0.27 \pm 0.04$ (average \pm standard deviation) nanomoles/g fresh weight (nmoles/gFW) in noninoculated plants. However, levels of free SA began to rise by $12 \mathrm{~h}$ and increased to the highest level by $72 \mathrm{~h}$ of pathogen inoculation (3.3-, 6- and 5.4-fold increase between 48 and $96 \mathrm{~h}$ compared with noninoculated plants; $P=$ $0.0019,0.0042$, and 0.0009 , respectively) (Fig. 2A). On the other hand, levels of SAG did not vary considerably between the $M$. oryzae conidia inoculated and noninoculated plants, with only $\approx 1.4$-fold increase of pathogen by $96 \mathrm{~h}$ post inoculation (hpi) (Fig. 2B).

Effect of $\mathrm{SA}$ and $\mathrm{BTH}$ treatments on relative expression levels of $P R-1$. The untreated control and $1.5 \mathrm{mM}$ SA-treated plants demonstrated relatively low levels of $P R-1$ activation compared with BTH-treated plants. In untreated control plants, expression level of $P R-1$ started to differ significantly at $48 \mathrm{hpi}$ (23.7-fold increase from 0 hpi, $P=0.005$ ) compared with 0 hpi (Fig. 3A, black bars). Similar expression patterns and significance levels of $P R-1$ were also observed with SA-treated plants (Fig. $3 \mathrm{~A}$, white bars). However, there were no significant differences $(P \leq 0.05)$ between SA-treated and untreated control plants at any time point of sample collection. Treatment with $1.0 \mathrm{mM} \mathrm{BTH}$, on the other hand, exhibited a significant increase of $P R-1$ at $48 \mathrm{hpi}$ (6.8-fold increase from 0 hpi, $P=0.0005)$ and $72 \mathrm{~h}$ (10.1-fold increase from 0 hpi, $P<0.0001$ ) following $M$. oryzae conidia inoculation on perennial ryegrass (Fig. 3A, striped bars). Furthermore, relative abundance of $P R-1$ was significantly greater throughout the course of the experiment in BTH-treated plants when compared with the untreated control $(0,12,24,48$, and 72 hpi; $P=0.0012, P=0.0356, P<0.0001, P=0.0103$, and $P=$ 0.0067 , respectively) and SA-treated plants $(0,12,24,48$, and 72 hpi; $P=0.0008, P=0.029, P<0.0001, P=0.0058$, and $P=$ 0.0049 , respectively).
Effect of SA and BTH treatments on relative expression levels of $\boldsymbol{P R}$-3.1. Infection with $M$. oryzae conidia did not change the expression level of $P R-3.1$ in perennial ryegrass until $48 \mathrm{hpi}$ (8.8-fold increase from 0 hpi, $P=0.0044$ ) (Fig. 3B, black bars).
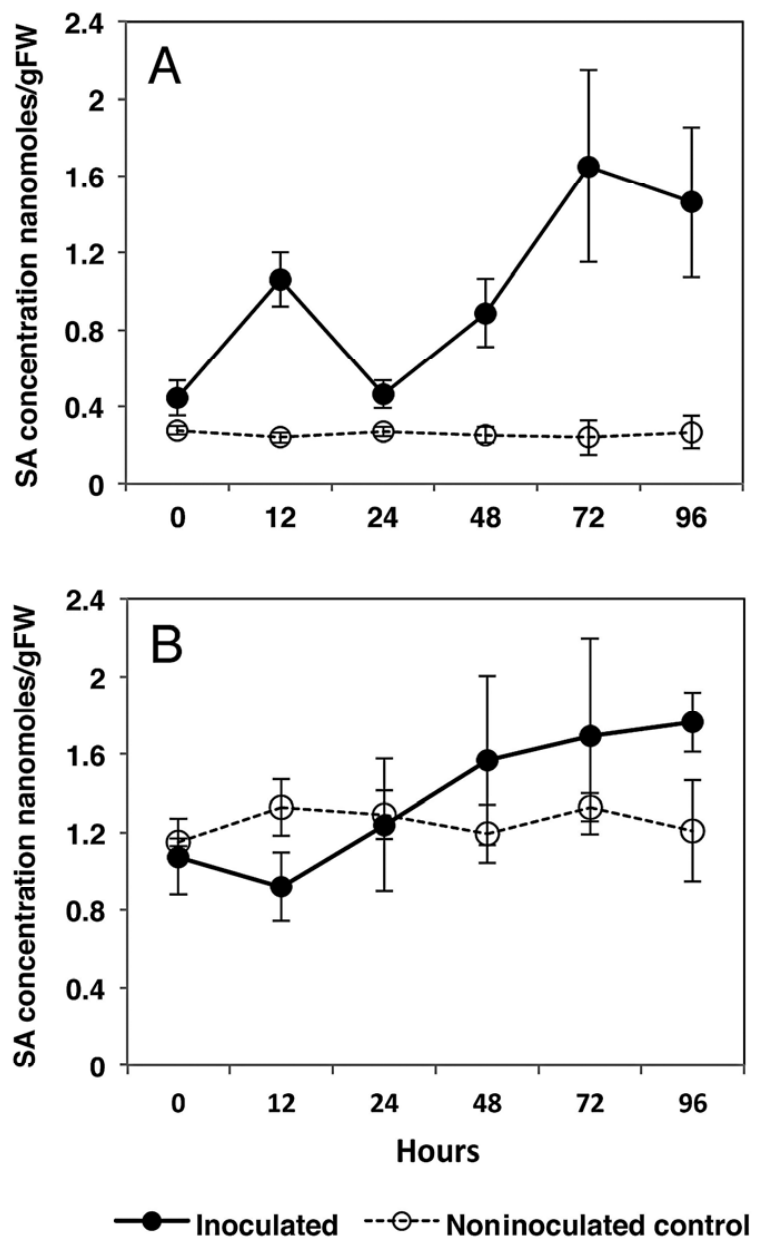

Fig. 2. Levels of endogenous $\mathbf{A}$, free salicylic acid (SA) and B, salicylic acid conjugates (salicylic acid-2-O- $\beta$-D-glucoside) in Magnaporthe oryzaeinoculated and noninoculated control plants. The 4-week-old plants were inoculated with $M$. oryzae conidia and leaf samples were collected at the time points indicated. Control plants treated with water $(0.01 \%$ Tween 20$)$ were also collected for endogenous free SA determination at the same time points. Open circle $=$ noninoculated control and black circle $=M$. oryzae inoculated . Error bars represent standard deviation of mean from three replicates.

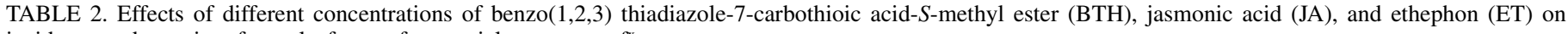
incidence and severity of gray leaf spot of perennial ryegrass turf ${ }^{\mathrm{x}}$

\begin{tabular}{|c|c|c|c|c|c|}
\hline \multirow[b]{2}{*}{ Treatment } & \multirow[b]{2}{*}{ Concentration (mM) } & \multicolumn{2}{|c|}{ Disease incidence $(\%)^{\mathrm{y}}$} & \multicolumn{2}{|c|}{ Disease severity $(\%)^{\mathrm{z}}$} \\
\hline & & Symptomatic & Control & Necrotic area & Control \\
\hline Untreated control & $\ldots$ & $84.64 \pm 3.40 \mathrm{a}$ & $\ldots$ & $42.19 \pm 4.49 \mathrm{a}$ & $\ldots$ \\
\hline \multirow[t]{3}{*}{ BTH } & 1.0 & $54.36 \pm 0.97 \mathrm{bc}$ & 35.77 & $19.12 \pm 0.98 \mathrm{bc}$ & 54.68 \\
\hline & 2.5 & $48.81 \pm 1.94 \mathrm{c}$ & 42.33 & $16.40 \pm 1.53 \mathrm{c}$ & 61.11 \\
\hline & 5.0 & $42.61 \pm 1.63 \mathrm{c}$ & 49.65 & $12.97 \pm 0.64 \mathrm{c}$ & 69.25 \\
\hline \multirow[t]{3}{*}{ JA } & 0.1 & $85.05 \pm 1.90 \mathrm{a}$ & -0.48 & $46.24 \pm 2.19 \mathrm{a}$ & -9.50 \\
\hline & 0.5 & $92.96 \pm 1.50 \mathrm{a}$ & -9.80 & $56.56 \pm 2.04 \mathrm{a}$ & -34.04 \\
\hline & 1.0 & $85.85 \pm 1.76 \mathrm{a}$ & -1.40 & $47.51 \pm 1.97 \mathrm{a}$ & -12.59 \\
\hline \multirow[t]{3}{*}{ ET } & 0.5 & $57.39 \pm 1.74 \mathrm{bd}$ & 32.19 & $26.35 \pm 1.26 \mathrm{bd}$ & 37.54 \\
\hline & 2.5 & $66.60 \pm 1.51 \mathrm{ad}$ & 21.31 & $30.11 \pm 1.27 \mathrm{ad}$ & 28.64 \\
\hline & 5.0 & $63.56 \pm 2.03 \mathrm{ad}$ & 24.90 & $33.46 \pm 1.50 \mathrm{ad}$ & 20.70 \\
\hline
\end{tabular}

${ }^{\mathrm{x}}$ Numbers followed by different letters within a column are significantly different according to Student-Newman-Keul's multiple range test $(P<0.05)$.

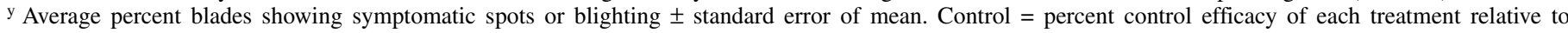
untreated control. Percent control was calculated as $100-x / y \times 100$, where $x=$ mean disease incidence in treated plants and $y=$ mean disease incidence in untreated control plants.

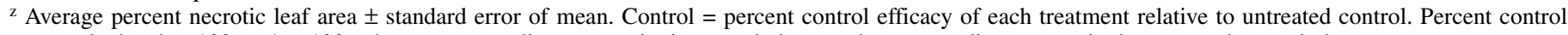
was calculated as $100-x / y \times 100$, where $x=$ mean disease severity in treated plants and $y=$ mean disease severity in untreated control plants. 
Both BTH- and SA-treated plants, on the other hand, exhibited gradual increase of $P R-3.1$ expression level over the course of experiment, reaching the highest level at 72 hpi $(2.87$-fold increase from $0 \mathrm{hpi}, P=0.019$, and 4.6-fold increase from $0 \mathrm{hpi}$, $P=0.0073$, respectively). BTH-treated plants exhibited a strong and rapid activation of the $P R-3.1$ gene following pathogen inoculation (Fig. 3B, striped bars). Levels remained elevated throughout the experiment, with significantly higher fold change values than the untreated control plants (51-fold higher at $12 \mathrm{hpi}$, 50.5 -fold higher at $24 \mathrm{hpi}, 4.2$-fold at $48 \mathrm{hpi}$, and 3.8 -fold at 72 hpi; $P=0.0017,0.0294,0.0173$, and 0.0002, respectively). Although SA treatment caused higher expression of the $P R-3$ gene compared with untreated control plants, apart from 0 hpi (6.9-fold higher, $P=0.0441)$, there were no significant difference between them at any other time points $(P>0.05)$.

Effect of SA and BTH treatments on relative expression levels of $\boldsymbol{P R}-5$. Activation of the $P R-5$ gene followed a similar pattern in all plants, treated or untreated (Fig. 3C). In the untreated-control plants, expression levels were significantly higher at 72 compared with 0 hpi (24.2-fold increase, $P=0.0013$ ) but not at any other time points of sample collection. However, in the SA-treated plants, a significant difference in expression level was observed at $24 \mathrm{hpi}(2.3$-fold increase from $0 \mathrm{hpi}, P=0.0055)$, 48 hpi (2.4-fold increase from 0 hpi, $P=0.0053)$, and 72 hpi (2.5fold increase from $0 \mathrm{hpi}, P=0.0031$ ). Also, there were significant differences between the SA-treated and untreated control plants at 24 hpi (19.2-fold increase, $P=0.0066)$ and 48 hpi (3-fold increase, $P=0.0082)$ but not at 72 hpi $(P>0.05)$. On other hand, BTH treatment resulted in a significantly higher level of $P R-5$ expression by $12 \mathrm{hpi}$ (3.4-fold increase from $0 \mathrm{hpi}, P=0.002$ ) followed by gradual increase throughout the course of experiment (Fig. 3C, striped bars). Moreover, BTH-treated and untreated control plants differed significantly in all four sampling time points after $M$. oryzae conidia inoculation (72-fold at 12,51 -fold at 24, 8.7-fold at 48, and 3-fold higher at $72 \mathrm{hpi} P<0.0001$ and $P=0.0001,0.0001$, and 0.021, respectively). BTH-treated plants also exhibited significantly higher upregulation of $P R-5$ compared with SA-treated plants at 12 hpi $(P<0.0001), 24$ hpi $(P=$ $0.0001), 48$ hpi $(P=0.0001)$, and 72 hpi $(P=0.0269)$.

Callose deposition at infection sites. In total, 30 cut leaf blade samples for each treatment at each time point (24, 48, and $72 \mathrm{hpi})$ were analyzed under a microscope for callose deposition. When present, callose deposition either prevented penetration of the appressorial penetration peg or often formed a haustorial collar neck if the callose barrier was breached (64). In all experiments, callose deposition was observed regardless of the treatment after pathogen inoculation from $24 \mathrm{hpi}$ (Table 3) but without any significant difference among the treatments $(P \leq 0.05)$. Although $1.0 \mathrm{mM}$ BTH treatment resulted in a significantly higher $(P<$ $0.0001)$ proportion of callose deposition at 48 and $72 \mathrm{hpi}$, SA $(1.5 \mathrm{mM})$ treatment was found to be significant only at $72 \mathrm{hpi}$ $(P=0.0001)$ compared with callose deposited on untreated control plants' infection sites. Nonetheless significantly higher percentage of deposited callose was penetrated by the fungal penetration peg in untreated control plants compared to BTH $(P<$ $0.0001)$ and SA $(P=0.0051)$ treated plants (Table 3$)$.

\section{DISCUSSION}

To our knowledge, this is the first documentation of the role of SA-mediated defense response in the gray leaf spot-perennial ryegrass pathosystem. Studies have shown that induced resistance to manage fungal diseases using SAR activators has been found to be effective in many eudicotyledonous (18) and monocotyledonous (1) plants. However, compared with dicot plants, the role of SA during SAR activation in monocots is yet to be clearly defined (1). Nevertheless, Shimono et al. (46) demonstrated that the WRKY45 transcription factor plays a pivotal role in BTH- and
SA-induced defense response in rice against $M$. oryzae infection (46). By generating WRKY-45 knockdown (WRKY45-kd) transgenic rice lines, they showed that $\mathrm{BTH}$-induced blast resistance was markedly reduced in WRKY45-kd plants compared with wildtype rice plants (46). Subsequently, they also demonstrated that
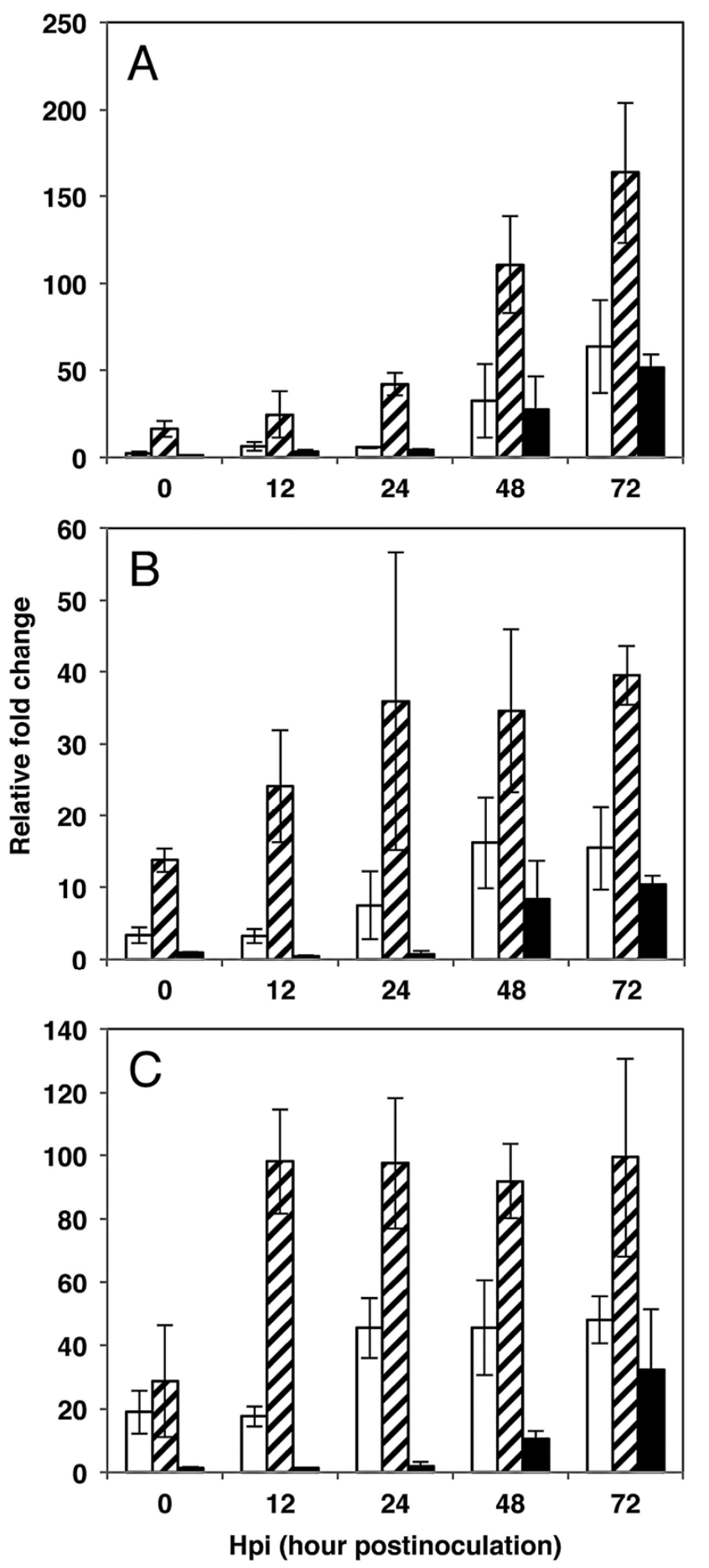

\section{口SA treated $\square_{\mathrm{BTH}}$ treated $\square$ Untreated control}

Fig. 3. Expression pattern of perennial ryegrass A, pathogenesis-related $(P R)-1$; B, $P R-3.1$; and C, $P R-5$ genes following inoculation with Magnaporthe oryzae. Solid white bars $=1.5 \mathrm{mM}$ salicylic acid (SA)-treated plants, stripped bars $=1.0 \mathrm{mM}$ benzothiadiazole $(\mathrm{BTH})$-treated plants, and black bars = untreated control plants. Each bar represents average relative expression ( \pm standard deviation) of $P R$ gene normalized to the stably expressed eukaryotic elongation factor $1 \alpha(e E F 1 A(s))$ housekeeping gene for three replicates. Fold changes were calculated by calibrating data to the $0 \mathrm{~h}$ post inoculation (hpi) untreated healthy plants. 
blast resistance in $W R K Y$-45 overexpressing (WRKY45-ox) transgenic rice lines is mediated through accumulation of $\mathrm{H}_{2} \mathrm{O}_{2}$ (45). However, the role of such a family of transcription factors in other monocots has not been determined. Furthermore, depending on the pathogen, different chemical SAR activators differ considerably in activating systemic resistance within different monocotyledonous plants (1). The results from this study showed that the SA-mediated defense response is activated in perennial ryegrass following $M$. oryzae infection. Additionally, activation of SAR through exogenous application of SA and BTH can effectively suppress gray leaf spot disease in this turfgrass species.

Treatment of $1.5 \mathrm{mM} \mathrm{SA}$ on 4-week-old perennial ryegrass plants, 2 days prior to pathogen inoculation, was found to be sufficient for effectively suppressing gray leaf spot disease, as demonstrated by $\approx 27$ and $19 \%$ reduction of disease incidence and severity, respectively, in this study (Fig. 1A and B). The only previous report on perennial ryegrass-SA interaction on gray leaf spot disease development documented that foliar application of $2.0 \mathrm{mM}$ SA 1 day prior to pathogen inoculation was ineffective in suppressing gray leaf spot disease incidence on 2-week-old plants only (49). Based on the data presented here and the previous study (49), suppression of disease development in perennial ryegrass seems to be fully congruent with at least two other monocots' defense responses; for example, application of exogenous SA has been found to be able to protect rice (only 4-weekold and not 2-week-old plants) from blast fungus (15) and wheat (only 2- and 3-week-old plants) against the common bunt pathogen (Tilletia laevia Kühn) (25). As suggested in both rice and wheat, genetic control of the phase change from juvenile to adult that results in fundamental reprogramming of gene expression and transcription could be responsible for the responsiveness of more mature 4-week-old perennial ryegrass plants to SA and SAR activators $(15,25)$. Also, SA treatment has been shown to protect barley from powdery mildew (B. graminis f. sp. hordei) disease (2). Application of BTH, on the other hand, was found to be more effective than SA in suppressing gray leaf spot disease (Table 2). Although there were no statistically significant differences among the BTH treatments $(1.0,2.5$, and $5.0 \mathrm{mM})$, the higher rate $(5.0 \mathrm{mM} \mathrm{BTH})$ exhibited 49.65 and $69.25 \%$ reduction of disease incidence and severity, respectively, which were the highest among the three treatments (Table 2). During the visual assessment of the ryegrass plants, there was no indication of phytotoxicity at any of the rates tested in this study. Effectiveness of BTH in suppressing blast disease in rice (27), and powdery mildew in wheat (10) and barley (2) were also found to be more effective than SA treatment, whereas a reduction in downy mildew disease incidence in maize (31) was observed with BTH seed treatment. Thus, usage of plant defense activators such as SA and its chemical analog, BTH, seem to be similarly effective on

TABLE 3. Callose deposition on perennial ryegrass leaf blades at Magnaporthe oryzae infection sites during different time points

\begin{tabular}{lccc}
\hline & \multicolumn{3}{c}{ Interaction sites with deposited callose $(\%)^{\mathrm{y}}$} \\
\cline { 2 - 4 } Time (hpi) & Untreated control & BTH treated & SA treated \\
\hline 24 & $20 \mathrm{a}$ & $21 \mathrm{a}$ & $20 \mathrm{a}$ \\
48 & $20 \mathrm{a}$ & $34 \mathrm{~b}$ & $22 \mathrm{a}$ \\
72 & $21 \mathrm{a}$ & $40 \mathrm{~b}$ & $25 \mathrm{c}$ \\
Nonpenetrated $^{\mathrm{z}}$ & & & \\
72 & $21 \mathrm{a}$ & $35 \mathrm{~b}$ & $27 \mathrm{c}$ \\
\hline
\end{tabular}

${ }^{y}$ Data represent the mean of $>100$ interaction sites on a total of 10 leaf segments $(3 \mathrm{~cm}$ each $)$ at each time point with three replicates. BTH $=$ benzo $(1,2,3)$ thiadiazole-7-carbothioic acid- $S$-methyl ester and $\mathrm{SA}=$ salicylic acid. Values followed by different letters within the row are significantly different according to Tukey's multiple comparison test $(P<0.05)$.

${ }^{\mathrm{z}}$ Percentage of callose deposited sites that were non-penetrated by $M$. oryzae penetration peg at the designated time point. perennial ryegrass as on other reported monocots in suppressing biotrophic fungal disease. In contrast, JA application appears to make perennial ryegrasses reproducibly more susceptible to $M$. oryzae infection than the untreated control plants (Table 2). Regardless of the application method, foliar spray or root drench (data not shown), JA was found to enhance disease susceptibility of perennial ryegrass to $M$. oryzae infection. These data, however, provide a sharp contrast with that of rice (27) and wheat (25), where JA application was found to be more protective than SA against $M$. oryzae and T. laevia (Kühn), respectively. One possible reason for this could be the antagonistic effects of SA- and JAsignaling pathways on each other, as seen in several dicots (3). However, further investigation of other physiological and molecular effects of JA on perennial ryegrass needs to be performed before drawing any conclusion. Another plant hormone, ethylene, has been shown to play a role in disease development in both dicots (57) and monocots (47). Protection of plants through production of defense-related proteins and phytoalexins, and activation of $P R$ genes by ethylene, has been documented (47). In this study, only $0.5 \mathrm{mM}$ ET was found to be effective in suppressing gray leaf spot disease in perennial ryegrass whereas higher concentrations increased susceptibility (Table 2). A similar increase in susceptibility with increasing ET concentrations was also observed in the rice-blast fungus interaction (47). Complex interactions (both synergistic and antagonistic) between the ethyleneand SA-signaling pathways are known to exist which may be responsible for such discrepancies (57).

Because application of SA and BTH, which induces SAR by acting on the SA-signaling pathway (63), provided protection against gray leaf spot disease, endogenous SA concentration in perennial ryegrass in relation to $M$. oryzae inoculation was examined. Noninfected plants showed fairly low levels of endogenous free SA $(<50 \mathrm{ng} / \mathrm{g} \mathrm{FW})$ (Fig. 2A) that are much lower than that in rice $(>1 \mu \mathrm{g} / \mathrm{g} \mathrm{FW})(15,62)$ but similar to that in barley $(<50$ ng/g FW) (56). Infection with $M$. oryzae caused greater than sixfold increase in free SA levels by 72 hpi (Fig. 2A). This accumulation of free SA exhibited a biphasic increase, having the first peak at $12 \mathrm{~h}$, then again at $72 \mathrm{~h}$, thereby reaching a plateau. A similar elevation pattern of free SA has been reported by Malamy et al. (26) in Tobacco mosaic virus-infected leaves of tobacco plants. Although no elevation in the endogenous free SA levels was noted in rice-blast fungus (15) and barley-powdery mildew (56) interactions, infection of maize by Bipolaris maydis (Y. Nisik. \& C. Miyake) Shoemaker reportedly caused an increased accumulation of free SA level (31). However, it is worth mentioning that another SAR activator, probenazole, which works upstream of the SA-signaling pathway (63), was shown to increase free endogenous SA level in 4-week-old rice plants, thereby suppressing blast disease (15). A moderate level of SAG $(<200 \mathrm{ng} / \mathrm{g} \mathrm{FW})$, thought to be an inactive and stored form of SA (60), was found in uninfected perennial ryegrass plants and increased only marginally by 96 hpi (Fig. 2B). However, it was noteworthy to observe that, at $12 \mathrm{hpi}$, there was a rise in free SA level but a decrease in SAG level. It may be possible that a major amount of endogenous free SA was generated through decomposition of SAG by $12 \mathrm{~h}$ following $M$. oryzae conidia inoculation, which was then replenished by continued accumulation of both free SA and SAG during later time periods in infected perennial ryegrass plants. Accumulation of endogenous free SA in plants following pathogen infection has been documented to be due to de novo synthesis as well as breakdown of SAG and other conjugated SA forms (60).

This research demonstrates, for the first time, the novel finding that $P R-1, P R-3.1$, and $P R-5$ genes are upregulated following treatments with SAR activators and $M$. oryzae infection in perennial ryegrass. Both $M$. oryzae infection and $\mathrm{BTH}$ treatment activated $P R-1$ and $P R-5$ in a fashion similar to that of the riceblast fungus interaction (27). Expression of $P R-1$ and $P R-5$ in 
barley (56) and maize (31) were also enhanced following fungal infection and BTH treatment. Although wheat $P R-1.1$ and $P R-1.2$ were found to be elicited by fungal infections and not by SAR activators, $P R-5$ expression, on the other hand, was augmented by both fungal infections and treatment with SA, BTH, and DCINA (30). Thus, cellular augmentation of $P R-5$ gene expression by SAR activators and fungal pathogen infection in perennial ryegrass appears to be consistent with other monocots. Relative expression of $P R-3.1$ was found to be increased negligibly by $M$. oryzae infection compared with early augmentation by BTHand SA-pretreated perennial ryegrass plants. Similar enhancement of $P R-3$ family genes has also been noted in rice-blast fungus (15) and wheat-bunt fungus (25) interactions following pretreatment with SAR activators. Additionally, among dicots, tomato cultivars resistant to early blight disease (Alternaria solani (Ellis \& G. Martin) L. R. Jones \& Grout) were documented to produce constitutively more $P R-1$ and $P R-3$ genes than susceptible cultivars (20).

The induction of $P R-1$ and $P R-5$ genes in dicotyledonous plants has been found to be a reliable indicator of SAR but is not true for all well-known monocots (1). Although BTH exhibited an early and strong (within $24 \mathrm{~h}$ ) induction of $P R-1, P R-3.1$, and $P R-5$, SA exhibited relatively weak induction of only $P R-3.1$ and $P R-5$ in perennial ryegrass when applied 2 days prior to pathogen inoculation (Fig. 3). These results show that expression of these genes in perennial ryegrass is closely associated with gray leaf spot disease or states associated with enhanced suppression of the disease. Direct antimicrobial activities as well as indirect involvement in defense signaling in cohort with other components of plant defense machinery have been suggested for in all three of these $P R$ genes (58). The exact mechanisms of function of the PR-1 protein family are still unknown. However, tomato PR-1 protein was found to have inhibitory activity against oomycetes, whereas enhanced penetration by Blumeria graminis f. sp. hordei was reported in barley after silencing of $P R-1 b(58)$. Members of the PR-3 protein (endochitinase family) are known to be able to hydrolyze chitin of fungal cell wall (58). Transgenic Italian ryegrass ( $L$. multiflorum Lam.) expressing rice $P R-3$ (chitinase gene) has been shown to be more resistant against crown rust (Puccinia coronata) disease (51). Similarly, for the PR-5 protein family, a number of mechanisms in plant defense have been elucidated, including membrane-permealization, glucan binding and hydrolysis, and apoptosis, that contribute to inhibition of fungal growth and development (58). A PR-5-like (PR-5K) gene from Arabidopsis expressed in creeping bentgrass was found to be associated with delayed symptoms of dollar spot disease (Sclerotinia homeocarpa) (11). In the rice-blast fungus model system, $P R-1 a, P R-1 b, P R-1 c$, and $P R-5$ were shown to be induced faster and to a higher degree in the incompatible interaction compared with the compatible interaction (40). Similarly, in another model grass (Brachypodium distachyon), infection with $M$. oryzae resulted in more rapid expression of $P R-1$ and $P R-5$ in the resistant 'ABR5' than the susceptible 'ABR1' (43). The existing functional model of plant defense response holds that, in both susceptible (compatible interaction) and resistant (incompatible interaction) plant varieties, defense reaction is activated following pathogen infection but it is the speed and magnitude of such reaction that determines the resistance to the pathogen $(19,31)$. The time course of relative expression of $P R$ genes in perennial ryegrass presented here correlates with this existing paradigm in that SAR activator-pretreated plants exhibited an enhanced defense-related gene expression, thereby increasing resistance to gray leaf spot disease.

In response to infection by $M$. oryzae, perennial ryegrass leaf epidermal cells were found to deposit callose at the penetration sites in this study (Fig. 4). Callose ( $\beta-1,3$-glucan) is presumed to be one of the most important constituents of papillae to shield against penetration by fungal appressoria (21). Although callose deposition was observed regardless of treatment type, BTH- and SA-pretreated plants produced callose at fungal penetration sites at significantly higher frequencies than untreated control at $72 \mathrm{hpi}$ (Table 3). Furthermore, significantly more nonpenetrated papillae were observed in SAR activator-treated plants compared with untreated plants. In both wheat- (10) and barley-powdery mildew interactions (7), treatment with BTH was also reported to be associated with increased number of nonpenetrated papillae with deposited callose at the appressorial penetration sites. Papillae are known to be deposited regardless of a plant's resistance or susceptibility; however, the speed of deposition as well as composition of papillae appear to play a vital role in thwarting fungal penetration (64). Localization of PR proteins such as maize PR-1 (33) and tomato PR-5 (16) in cell wall appositions at the fungal penetration sites have been documented. Incidentally, data presented in this study show that $P R-1, P R-3.1$, and $P R-5$ expression levels in the SAR activator-treated perennial ryegrass $-M$. oryzae interaction correlate with the heightened accumulation of callose deposition at the fungal penetration sites.

In summary, this study demonstrated that exogenous applications of SAR activators such as SA and BTH reduce infection by $M$. oryzae through activation of multiple defense mechanisms in perennial ryegrass. However, the disease incidence and severity were reduced but not completely prevented in the susceptible perennial ryegrass Legacy II. The enhanced resistance against gray leaf spot disease observed in this cultivar with SAR activator treatment may be due to switching on of postpenetration resistance conferred by $P R$ genes or enhanced callose accumulation leading to more effective blockage of $M$. oryzae penetration pegs or both. The results obtained corroborate the conclusion that resistance in perennial ryegrass can be enhanced against $M$. oryzae using SAR activators. Given the enhanced protection obtained, it could be that several defense mechanisms need to function in concert for effective resistance to be manifested. These results are the first to implicate the SA defense pathway in the suppression of gray leaf spot disease in perennial ryegrass and will be useful in devising a management strategy incorporating defense gene regulators into fungicide program.

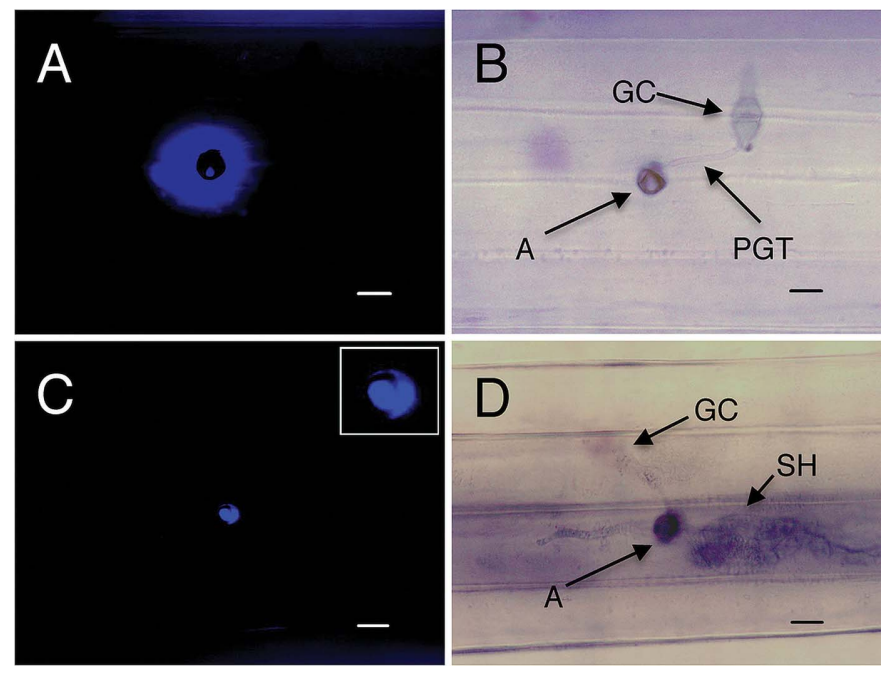

Fig. 4. Microscopic analysis of aniline-blue-stained callose deposition during Magnaporthe oryzae development on perennial ryegrass. Nonpenetrated papillae showing localized deposition of callose beneath the attempted penetration sites as seen by epifluoroscent microscopy with A, UV filter and B, white light. Penetrated callose deposited papilla on epidermal cell, as viewed by epifluoroscent microscopy with $\mathbf{C}$, UV filter and D, white light, in which $M$. oryzae has established secondary hyphae. A = appressorium, GC = germinating conidia, $\mathrm{PGT}=$ primary germ tube, and $\mathrm{SH}=$ secondary hyphae. Inset in $C$ is a greater view of the penetrated callose. $\mathrm{Bar}=10 \mu \mathrm{m}$. 


\section{ACKNOWLEDGMENTS}

We thank Dr. Timothy McNellis and Nancy Wenner for technical assistance. We also thank Huck Institute of Life Sciences and Genomic Core Facility, The Pennsylvania State University, University Park, for the facility use in this study.

\section{LITERATURE CITED}

1. Balmer, D., Planchamp, C., and Mauch-Mani, B. 2013. On the move: induced resistance in monocots. J. Exp. Bot. 64:1249-1261.

2. Beßer, K., Jarosch, B., Langen, G., and Kogel, K. H. 2000. Expression analysis of genes induced in barley after chemical activation reveals distinct disease resistance pathways. Mol. Plant Pathol. 1:277-286.

3. Boatwright, J. L., and Pajerowska-Mukhtar, K. 2013. Salicylic acid: an old hormone up to new tricks. Mol. Plant Pathol. 14:623-634.

4. Bowling, S. A., Guo, A., Cao, H., Gordon, A. S., Klessig, D. F., and Dong, X. I. 1994. A mutation in Arabidopsis that leads to constitutive expression of systemic acquired-resistance. Plant Cell 6:1845-1857.

5. Curley, J., Sim, S. C., Warnke, S., Leong, S., Barker, R., and Jung, G. 2005. QTL mapping of resistance to gray leaf spot in ryegrass. Theor. Appl. Genet. 111:1107-1117.

6. Dracatos, P., Cogan, N. O. I., Dobrowolski, M., Sawbridge, T., Spangenberg, G., Smith, K., and Forster, J. 2008. Discovery and genetic mapping of single nucleotide polymorphisms in candidate genes for pathogen defence response in perennial ryegrass (Lolium perenne L.). Theor. Appl. Genet. 117:203-219.

7. Faoro, F., Maffi, D., Cantu, D., and Iriti, M. 2008. Chemical-induced resistance against powdery mildew in barley: the effects of chitosan and benzothiadiazole. Biocontrol 53:387-401.

8. Geffroy, V., Sevignac, M., De Oliveira, J. C. F., Fouilloux, G., Skroch, P., Thoquet, P., Gepts, P., Langin, T., and Dron, M. 2000. Inheritance of partial resistance against Colletotrichum lindemuthianum in Phaseolus vulgaris and co-localization of quantitative trait loci with genes involved in specific resistance. Mol. Plant-Microbe Interact. 13:287-296.

9. Glazebrook, J. 2005. Contrasting mechanisms of defense against biotrophic and necrotrophic pathogens. Annu. Rev. Phytopathol. 43:205227.

10. Görlach, J., Volrath, S., Knauf-Beiter, G., Hengy, G., Beckhove, U., Kogel, K. H., Oostendorp, M., Staub, T., Ward, E., Kessmann, H., and Ryals, J. 1996. Benzothiadiazole, a novel class of inducers of systemic acquired resistance, activates gene expression and disease resistance in wheat. Plant Cell 8:629-643.

11. Guo, Z. F., Bonos, S., Meyer, W. A., Day, P. R., and Bélanger, F. C. 2003. Transgenic creeping bentgrass with delayed dollar spot symptoms. Mol. Breed. 11:95-101.

12. Halim, V. A., Eschen-Lippold, L., Altmann, S., Birschwilks, M., Scheel, D., and Rosahl, S. 2007. Salicylic acid is important for basal defense of Solanum tuberosum against Phytophthora infestans. Mol. Plant-Microbe Interact. 20:1346-1352.

13. Han, Y. H., Bonos, S. A., Clarke, B. B., and Meyer, W. A. 2006. Inheritance of resistance to gray leaf spot disease in perennial ryegrass. Crop Sci. 46:1143-1148.

14. Hood, M. E., and Shew, H. D. 1996. Applications of KOH-aniline blue fluorescence in the study of plant-fungal interactions. Phytopathology 86:704-708.

15. Iwai, T., Seo, S., Mitsuhara, I., and Ohashi, Y. 2007. Probenazole-induced accumulation of salicylic acid confers resistance to Magnaporthe grisea in adult rice plants. Plant Cell Physiol. 48:915-924.

16. Jeun, Y. C., and Buchenauer, H. 2001. Infection structures and localization of the pathogenesis-related protein AP24 in leaves of tomato plants exhibiting systemic acquired resistance against Phytophthora infestans after pre-treatment with 3-aminobutyric acid or tobacco necrosis virus. J. Phytopathol. 149:141-153.

17. Jo, Y. K., Barker, R., Pfender, W., Warnke, S., Sim, S. C., and Jung, G. 2008. Comparative analysis of multiple disease resistance in ryegrass and cereal crops. Theor. Appl. Genet. 117:531-543.

18. Kachroo, P., and Kachroo, A. 2012. The roles of salicylic acid and jasmonic acid in plant immunity. Pages 55-79 in: Molecular Plant Immunity, 1st ed. G. Sessa, ed. Wiley Online Library, John Wiley \& Sons, Inc., New York.

19. Kou, Y. J., and Wang, S. P. 2010. Broad-spectrum and durability: understanding of quantitative disease resistance. Curr. Opin. Plant Biol. 13:181-185.

20. Lawrence, C. B., Singh, N. P., Qiu, J. S., Gardner, R. G., and Tuzun, S. 2000. Constitutive hydrolytic enzymes are associated with polygenic resistance of tomato to Alternaria solani and may function as an elicitor release mechanism. Physiol. Mol. Plant Pathol. 57:211-220.

21. Lazniewska, J., Macioszek, V. K., and Kononowicz, A. K. 2012. Plant- fungus interface: the role of surface structures in plant resistance and susceptibility to pathogenic fungi. Physiol. Mol. Plant Pathol. 78:24-30.

22. Lee, J. M., Roche, J. R., Donaghy, D. J., Thrush, A., and Sathish, P. 2010. Validation of reference genes for quantitative RT-PCR studies of gene expression in perennial ryegrass (Lolium perenne L.). BMC Mol. Biol. $11: 8$.

23. Livak, K. J., and Schmittgen, T. D. 2001. Analysis of relative gene expression data using real-time quantitative PCR and the $2^{-\Delta \Delta \mathrm{Ct}}$ method. Methods 25:402-408.

24. Lu, S. W., Friesen, T. L., and Faris, J. D. 2011. Molecular characterization and genomic mapping of the pathogenesis-related protein 1 (PR-1) gene family in hexaploid wheat (Triticum aestivum L.). Mol. Genet. Genomics 285:485-503.

25. Lu, Z.-X., Gaudet, D., Puchalski, B., Despins, T., Frick, M., and Laroche, A. 2006. Inducers of resistance reduce common bunt infection in wheat seedlings while differentially regulating defence-gene expression. Physiol. Mol. Plant Pathol. 67:138-148.

26. Malamy, J., Carr, J. P., Klessig, D. F., and Raskin, I. 1990. Salicylic acid: a likely endogenous signal in the resistance response of tobacco to viralinfection. Science 250:1002-1004.

27. Mei, C. S., Qi, M., Sheng, G. Y., and Yang, Y. N. 2006. Inducible overexpression of a rice allene oxide synthase gene increases the endogenous jasmonic acid level, $P R$ gene expression, and host resistance to fungal infection. Mol. Plant-Microbe Interact. 19:1127-1137.

28. Mishina, T. E., and Zeier, J. 2007. Pathogen-associated molecular pattern recognition rather than development of tissue necrosis contributes to bacterial induction of systemic acquired resistance in Arabidopsis. Plant J. 50:500-513.

29. Mittapalli, O., Shukle, R. H., Sardesai, N., Giovanini, M. P., and Williams, C. E. 2006. Expression patterns of antibacterial genes in the Hessian fly. J. Insect Physiol. 52:1143-1152.

30. Molina, A., Görlach, J., Volrath, S., and Ryals, J. 1999. Wheat genes encoding two types of PR-1 proteins are pathogen inducible, but do not respond to activators of systemic acquired resistance. Mol. Plant-Microbe Interact. 12:53-58.

31. Morris, S. W., Vernooij, B., Titatarn, S., Starrett, M., Thomas, S., Wiltse, C. C., Frederiksen, R. A., Bhandhufalck, A., Hulbert, S., and Uknes, S. 1998. Induced resistance responses in maize. Mol. Plant-Microbe Interact. 11:643-658.

32. Munoz-Leoz, B., Ruiz-Romera, E., Antiguedad, I., and Garbisu, C. 2011. Tebuconazole application decreases soil microbial biomass and activity. Soil Biol. Biochem. 43:2176-2183.

33. Murillo, I., Cavallarin, L., and San Segundo, B. 1999. Cytology of infection of maize seedlings by Fusarium moniliforme and immunolocalization of the pathogenesis-related PRms protein. Phytopathology 89:737-747.

34. Muthukrishnan, S., Liang, G. H., Trick, H. N., and Gill, B. S. 2001. Pathogenesis-related proteins and their genes in cereals. Plant Cell Tiss. Org. 64:93-114.

35. Nanayakkara, U., Uddin, W., and Datnoff, L. 2008. Effects of soil type, source of silicon, and rate of silicon source on development of gray leaf spot of perennial ryegrass turf. Plant Dis. 92:870-877.

36. Orshinsky, A. M., Boehm, M. J., and Boland, G. J. 2012. Plant wounding and Ophiostoma mitovirus 3a (OMV3a) influence infection of creeping bentgrass by Sclerotinia homoeocarpa. Can. J. Plant Pathol. 34:493-506.

37. Park, S. W., Kaimoyo, E., Kumar, D., Mosher, S., and Klessig, D. F. 2007. Methyl salicylate is a critical mobile signal for plant systemic acquired resistance. Science 318:113-116.

38. Pieterse, C. M. J., Leon-Reyes, A., Van der Ent, S., and Van Wees, S. C. M. 2009. Networking by small-molecule hormones in plant immunity. Nat. Chem. Biol. 5:308-316.

39. Poland, J. A., Balint-Kurti, P. J., Wisser, R. J., Pratt, R. C., and Nelson, R. J. 2009. Shades of gray: the world of quantitative disease resistance. Trends Plant Sci. 14:21-29.

40. Ponciano, G., Yoshikawa, M., Lee, J. L., Ronald, P. C., and Whalen, M. C. 2006. Pathogenesis-related gene expression in rice is correlated with developmentally controlled Xa21-mediated resistance against Xanthomonas oryzae pv. oryzae. Physiol. Mol. Plant Pathol. 69:131-139.

41. Ran, Y., Ramage, C., Felitti, S., Emmerling, M., Chalmers, J., Cummings, N., Petrovska, N., Mouradov, A., and Spangenberg, G. 2007. Ryegrasses. Pages 373-395 in: Biotechnology in Agriculture and Forestry 61: Transgenic Crops VI. E. C. Pua and M. R. Davey, eds. Springer-Verlag, Berlin, Heidelberg.

42. Raskin, I., Turner, I. M., and Melander, W. R. 1989. Regulation of heatproduction in the inflorescences of an Arum lily by endogenous salicylic acid. Proc. Natl. Acad. Sci. USA 86:2214-2218.

43. Routledge, A. P. M., Shelley, G., Smith, J. V., Talbot, N. J., Draper, J., and Mur, L. A. J. 2004. Magnaporthe grisea interactions with the model grass Brachypodium distachyon closely resemble those with rice (Oryza sativa). Mol. Plant Pathol. 5:253-265. 
44. Sato, K., Inukai, T., and Hayes, P. M. 2001. QTL analysis of resistance to the rice blast pathogen in barley (Hordeum vulgare). Theor. Appl. Genet. 102:916-920.

45. Shimono, M., Koga, H., Akagi, A., Hayashi, N., Goto, S., Sawada, M., Kurihara, T., Matsushita, A., Sugano, S., and JIANG, C. J. 2012. Rice WRKY45 plays important roles in fungal and bacterial disease resistance. Mol. Plant Pathol. 13:83-94.

46. Shimono, M., Sugano, S., Nakayama, A., Jiang, C.-J., Ono, K., Toki, S., and Takatsuji, H. 2007. Rice WRKY45 plays a crucial role in benzothiadiazole-inducible blast resistance. Plant Cell 19:2064-2076.

47. Singh, M. P., Lee, F. N., Counce, P. A., and Gibbons, J. H. 2004. Mediation of partial resistance to rice blast through anaerobic induction of ethylene. Phytopathology 94:819-825.

48. Stadnik, M. J., and Buchenauer, H. 1999. Accumulation of autofluorogenic compounds at the penetration site of Blumeria graminis $\mathrm{f}$. sp. tritici is associated with both benzothiadiazole-induced and quantitative resistance of wheat. J. Phytopathol. 147:615-622.

49. Strobel, N. E. 2006. Inhibition of Pyricularia oryzae, the gray leaf spot pathogen of perennial ryegrass (Lolium perenne), by AH010, a novel fungicidal material. J. Ky. Acad. Sci. 67:117-124.

50. Tabien, R. E., Li, Z., Paterson, A. H., Marchetti, M. A., Stansel, J. W., and Pinson, S. R. M. 2002. Mapping QTLs for field resistance to the rice blast pathogen and evaluating their individual and combined utility in improved varieties. Theor. Appl. Genet. 105:313-324.

51. Takahashi, W., Fujimori, M., Miura, Y., Komatsu, T., Nishizawa, Y., Hibi, T., and Takamizo, T. 2005. Increased resistance to crown rust disease in transgenic Italian ryegrass (Lolium multiflorum Lam.) expressing the rice chitinase gene. Plant Cell Rep. 23:811-818.

52. Tanaka, A., Christensen, M. J., Takemoto, D., Park, P., and Scott, B. 2006. Reactive oxygen species play a role in regulating a fungus-perennial ryegrass mutualistic interaction. Plant Cell 18:1052-1066.

53. Tosa, Y., Uddin, W., Viji, G., Kang, S., and Mayama, S. 2007. Comparative genetic analysis of Magnaporthe oryzae isolates causing gray leaf spot of perennial ryegrass turf in the United States and Japan. Plant Dis. 91:517-524.

54. Tsuda, K., Sato, M., Glazebrook, J., Cohen, J. D., and Katagiri, F. 2008.
Interplay between MAMP-triggered and SA-mediated defense responses. Plant J. 53:763-775.

55. Uddin, W., Viji, G., and Vincelli, P. 2003. Gray leaf spot (blast) of perennial ryegrass turf: an emerging problem for the turfgrass industry. Plant Dis. 87:880-889.

56. Vallélian-Bindschedler, L., Métraux, J. P., and Schweizer, P. 1998. Salicylic acid accumulation in barley is pathogen specific but not required for defense-gene activation. Mol. Plant-Microbe Interact. 11:702-705.

57. van Loon, L. C., Geraats, B. P. J., and Linthorst, H. J. M. 2006. Ethylene as a modulator of disease resistance in plants. Trends Plant Sci. 11:184191.

58. van Loon, L. C., Rep, M., and Pieterse, C. M. J. 2006. Significance of inducible defense-related proteins in infected plants. Annu. Rev. Phytopathol. 44:135-162.

59. Vincelli, P., and Dixon, E. 2002. Resistance to $\mathrm{Q}_{\mathrm{O}} \mathrm{I}$ (strobilurin-like) fungicides in isolates of Pyricularia grisea from perennial ryegrass. Plant Dis. $86: 235-240$

60. Vlot, A. C., Dempsey, D. A., and Klessig, D. F. 2009. Salicylic acid, a multifaceted hormone to combat disease. Annu. Rev. Phytopathol. 47:177-206.

61. Wong, F., Gelernter, W., and Stowell, L. 2005. First report of Pyricularia grisea causing gray leaf spot on kikuyugrass (Pennisetum clandestinum) in the United States. Plant Dis. 89:433-433.

62. Yang, Y., Qi, M., and Mei, C. 2004. Endogenous salicylic acid protects rice plants from oxidative damage caused by aging as well as biotic and abiotic stress. Plant J. 40:909-919.

63. Yasuda, M., Ishikawa, A., Jikumaru, Y., Seki, M., Umezawa, T., Asami, T., Maruyama-Nakashita, A., Kudo, T., Shinozaki, K., Yoshida, S., and Nakashita, H. 2008. Antagonistic interaction between systemic acquired resistance and the abscisic acid-mediated abiotic stress response in Arabidopsis. Plant Cell 20:1678-1692.

64. Zeyen, R., Carver, T. L., Lyngkjaer, M. F., Bélanger, R., Bushnell, W., and Dik, A. 2002. Epidermal cell papillae. Pages 107-125 in: The Powdery Mildews: A Comprehensive Treatise. R. R. Belanger, W. R. Bushnell, A. J. Dik, and T. L. W. Carver, eds. American Phytopathological Society, St. Paul, MN. 